\section{Gamma-glutamyltransferase, $\mathrm{H}_{2} \mathrm{O}_{2}$-induced apoptosis and expression of catalase}

\section{Dear Editor:}

We would like to call the attention of the readers on a biochemical aspect generating occasional disputes in studies concerned with oxidative stress-related apoptosis. The paper recently published in this journal by Moon et al. (2012) documents that the mutation of K-RAS in prostate epithelial cells causes the activation of the ERK signalling pathway and an increased expression of gamma-glutamyltransferase-2 (GGT2). This was accompanied by a reduction in cellular production of reactive oxygen species (ROS) as well as by induction of resistance to $\mathrm{H}_{2} \mathrm{O}_{2}$-induced cell death. As GGT2 enzyme activity is known to contribute to maintenance of cellular homeostasis of glutathione (GSH), the authors conclude that the observed resistance to $\mathrm{H}_{2} \mathrm{O}_{2}$ is likely the result of increased intracellular levels of this major antioxidant. GSH levels in control and K-RAS-mutated cells were however not determined.

Our laboratory has repeatedly reported on the antiapoptotic effects of GGT expression, but a relationship with increased cellular GSH levels could never be confirmed (Del Bello et al., 1999; Franzini et al., 2006; Giommarelli et al., 2008). On the contrary, these studies highlighted how GGT expression actually results in a decrease of cellular GSH levels, likely due to the (often overlooked) prooxidant role of this enzyme activity. Indeed, an apparent 'GSH oxidase' activity of GGT was described since earlier studies (Tate et al., 1979), and more recently it was shown that generation of prooxidant species, including $\mathrm{H}_{2} \mathrm{O}_{2}$ itself, can occur during GGT activity following the interaction of the GSH metabolite cysteinyl-glycine with redox-active transition metals, notably iron (Dominici et al., 1999).

The prooxidant effects of GGT activity were shown to produce significant changes in the cell redox status, exerting modulatory effects on several molecular targets in signal transduction pathways (reviewed in Dominici et al. (2005)). With regard to apoptosis, we have shown that the increased resistance of GGT-expressing cells to $\mathrm{H}_{2} \mathrm{O}_{2}$-induced apoptosis is not related to intracellular GSH content, but rather results from activation of ASK-1/p38 signalling and increased expression of cellular catalase, resulting in decreased ROS formation and protection against ROSinduced DNA damage (Giommarelli et al., 2008, 2009). Interestingly, besides the phenomena described by Moon et al. in K-RAS transformed cells, the described mechanisms likely account for the resistance of GGT-expressing cells to apoptosis induced by cytotoxic agents (Giommarelli et al., 2009; Corti et al., 2010). Altogether, the functions played by GGT activity in cellular homeostasis may be more complex than traditionally appreciated, and caution should be put in interpreting the effects of GGT expression solely in terms of cellular GSH supply.

\section{Conflict of interest statement}

None declared.

\section{References}

Corti, A., Franzini, M., Paolicchi, A., Pompella, A., 2010. Gamma-glutamyltransferase of cancer cells at the crossroads of tumor progression, drug resistance and drug targeting. Anticancer Res. 30, 1169-1181.

Del Bello, B., Paolicchi, A., Comporti, M., Pompella, A., Maellaro, E., 1999. Hydrogen peroxide produced during gamma-glutamyl transpeptidase activity is involved in prevention of apoptosis and maintainance of proliferation in U937 cells. Faseb J. 13, 69-79.

Dominici, S., Valentini, M., Maellaro, E., Del Bello, B., Paolicchi, A., Lorenzini, E., Tongiani, R., Comporti, M., Pompella, A., 1999. Redox modulation of cell surface protein thiols in U937 lymphoma cells: the role of gamma-glutamyl transpeptidase-dependent $\mathrm{H}_{2} \mathrm{O}_{2}$ production and S-thiolation. Free Rad. Biol. Med. 27, 623-635.

Dominici, S., Paolicchi, A., Corti, A., Maellaro, E., Pompella, A., 2005. Prooxidant reactions promoted by soluble and cell-bound $\gamma$-glutamyltransferase activity. Methods Enzymol. 401, 483-500.

Franzini, M., Corti, A., Lorenzini, E., Paolicchi, A., Pompella, A., De Cesare, M., Perego, P., Gatti, L., Leone, R., Apostoli, P., Zunino, F., 2006. Modulation of cell growth and cisplatin sensitivity by membrane -glutamyltransferase in melanoma cells. Eur. J. Cancer 42, 2623-2630.

Giommarelli, C., Corti, A., Supino, R., Favini, E., Paolicchi, A., Pompella, A., Zunino, F., 2008. Cellular response to oxidative stress and ascorbic acid in melanoma cells overexpressing gamma-glutamyltransferase. Eur. J. Cancer 44, 750-759.

Giommarelli, C., Corti, A., Supino, R., Favini, E., Paolicchi, A., Pompella, A., Zunino, F., 2009. Gamma-glutamyltransferase-dependent resistance to arsenic trioxide in melanoma cells and cellular sensitization by ascorbic acid. Free Radic. Biol. Med. 46, 1516-1526.

Moon, D.O., Kim, B.Y., Jang, J.H., Kim, M.O., Jayasooriya, R.G., Kang, C.H., Choi, Y.H., Moon, S.K., Kim, W.J., Ahn, J.S., Kim, G.Y., 2012. K-RAS transformation in prostate epithelial cell overcomes $\mathrm{H} 2 \mathrm{O} 2$-induced apoptosis via upregulation of gamma-glutamyltransferase-2. Toxicol. In Vitro 26, 429-434.

Tate, S.S., Grau, E.M., Meister, A., 1979. Conversion of glutathione to glutathione disulfide by cell membrane-bound oxidase activity. Proc. Natl. Acad. Sci. USA 76, 2715-2719.

Alfonso Pompella* Aldo Paolicchi

Alessandro Corti

Dept. of Experimental Pathology, University of Pisa Medical School,

Via Roma 55, 56126 Pisa, Italy

* Tel.: +39050 2218 537; fax: +39050 2218557.

E-mail address: alfonso.pompella@med.unipi.it (A. Pompella)

Maria Franzini Scuola Superiore S. Anna di Studi Universitari e di Perfezionamento, Piazza Martiri della Libertà 33, 56127 Pisa, Italy 